\title{
Baffling Variety: Education Methods For Librarianship in Great Britain, Canada, and the United States
}

By A. ROBERTS ROGERS

Plagued by a chronic shortage of professional staff, an American library administrator places an advertisement in The Times Literary Supplement. To his delight, six replies arrive: three from Great Britain and three from Canada. But pleasure quickly turns to despair as he reads the letters of application. Here, surely, are the qualified people he is looking for. But which ones? Apart from the usual problems of personal suitability and length and type of professional experience, the mere assessment of educational qualifications poses baffling questions.

The first letter is from Ilif Evans, A.L.A., who says that he has the G.C.E. with two passes at the A level and has recently been elected to the Register. What on earth is the G.C.E.? And A.L.A. must stand for something other than American Library Association. But what?

Then, there is John Vickery, who has a B.A. from Oxford with First Class Honours in History and the Academic Post Graduate Diploma in Librarianship from the University of London. No doubt about the excellence of his undergraduate education. But what about that diploma from London? Does it compare with an American master's degree in library science? If it does, why a diploma and not a degree?

Finally, there is Alexander MacDonald, F.L.A., who has an M.A. degree from the University of Aberdeen. That, at least, looks familiar. But it is not an M.A. in library science. And what about
Mr. Rogers is Assistant to the Director, Bowling Green (Ohio) State University $\mathrm{Li}$ brary.

those mysterious letters F.L.A. after his name?

Perhaps the Canadian applications will pose fewer problems. Joan Scott has a B.A. (general) from Queen's University, and both the B.L.S. and M.L.S. from McGill. Why the two professional degrees? Anne Johnson has a B.A. from the University of Toronto with Second Class Honours in English. Her B.L.S. is from the same institution. How do her qualifications compare with those of Joan Scott and with those of the average graduate of an American library school? Jean Belliveau has his B.A. from Laval and his B.L.S. from the University of Ottawa. How are his qualifications to be equated?

To find the answers to these questions, it is necessary to examine in some detail both the general educational systems of Great Britain and Canada and the specific methods of training for librarianship.

Compulsory free public education in Britain begins at the age of five. Completion of primary school at the age of eleven-plus brings the British child to the point at which his educational destiny is usually determined. On the basis of a battery of psychological tests, his previous record, and his performance on 
an examination in English, arithmetic, and general knowledge, a decision is reached as to the kind of secondary education best fitted to his abilities.

\section{Three SEcondary Schools in BRITAIN}

There are three types of secondary schools in Britain. The student who is academically gifted and wishes to prepare for admission to a university or entrance into one of the professions is sent to a grammar school, where he receives a non-vocational, liberal education. The student who already has a definite trade in mind and shows the necessary aptitude is sent to a technical school. A student who does not clearly belong in either of these categories will attend a secondary modern school where every effort will be made to provide a sound terminal education.

Upon completion of the fifth form (usually around age sixteen), students write a set of examinations prepared by the Ministry of Education. Success in passing these leads to the award of the General Certificate of Education at the Ordinary level-G.C.E.(O).This is the terminal point in the education of the overwhelming majority of young people in Britain. However, the academically gifted may continue to complete the sixth form, which takes another two years. Courses at the sixth form level are both advanced and specialized. Success in the examinations set by the Ministry of Education leads to the award of the General Certificate of Education at the Advanced level-G.C.E.(A). The General Certificate of Education at the Ordinary level is the equivalent of high school graduation in the United States and the Certificate at the Advanced level is approximately the equivalent of junior college.

Because of the extensive system of private scholarships, state scholarships, and grants from local authorities, the barriers to higher education in Britain tend to be academic rather than economic. Nevertheless, they are formidable. University expansion since the war has not kept pace with demand. Classroom and laboratory space is at a premium. Competition is so keen that only students with the best grades can hope to be admitted. About 6 per cent of British youth of college age attend university compared with about 30 per cent of American young people.

The degree and diploma structure of British universities is sometimes confusing to Americans. The subject may be analyzed under three headings: (1) first degrees, (2) higher degrees, and (3) higher diplomas. With the exception of Scotland (where the first degree is customarily the M.A.), first degrees are at the bachelor's level. A pass degree is awarded after a course of general study. An honours degree requires concentration in a specialized field and successful completion of a comprehensive examination. Higher degrees are of three sorts: masterships; the Ph.D.; and the senior doctorates. In addition to higher degrees, there are several higher diplomas. British universities have been more conservative than American in the matter of awarding degrees, particularly in professional and technical subjects. As a result, various higher diplomas are awarded upon successful completion of a year or more of study at the graduate level. These are often the equivalent of American master's degrees.

The British pattern of education for librarianship differs in a number of important respects from the American. In the first place, certification of individuals is emphasized rather than accreditation of schools. The Library Association sets its own examinations and admits to the Register of Chartered Librarians, as Associates or as Fellows, members in good standing who have successfully completed the appropriate examinations. Secondly, it is possible for people who are not university graduates to become 
chartered librarians. Finally, it is not necessary to attend a library school in order to prepare for the L.A. examinations, though the association strongly advises candidates to do so.

\section{The Association's Examinations}

The First Professional Examination is essentially a preliminary screening device. The minimum educational requirement is the General Certificate of Education with five passes at the Ordinary level, or four passes if at least one is at the Advanced level. English language is one of the required subjects. In addition, the candidates should have some practical library experience and should supplement this with spare-time study of topics indicated in the syllabus contained in the Students' Handbook. University graduates are exempted from this examination upon payment of a small fee.

The next step up the professional ladder is the Registration Examination. If a candidate (a) passes this examination, (b) has reached age twenty-three, (c) has satisfied the foreign language requirement, and (d) has had at least three years of satisfactory full-time paid service in a library approved by the Library Association, he may apply for election to the Register as an Associate of the Library Association. Upon acceptance, he will be entitled to use the letters A.L.A. after his name and to designate himself as a Chartered Librarian as long as he remains a member of the association.

The Registration Examination consists of the following seven papers: classification; cataloguing; practical classification and cataloguing; bibliography and documentary reproduction; assistance to readers; organization and administration; literature of a special subject.

For those who desire the advanced training that is now generally required for top administrative posts, the next step is the Final Examination. A candidate who (a) successfully completes this, (b) is at least twenty-five years of age, and (c) has completed five years of approved full-time paid service may apply for election to the Register as a Fellow of the Library Association. If his application is accepted, he is entitled to use the letters F.L.A. after his name and to describe himself as a Chartered $\mathrm{Li}$ brarian as long as he remains a member of the association.

Candidates formerly prepared for the L.A. examinations by study in their spare time, assisted by correspondence courses, evening classes, and short courses that lasted from a day to a week or more. The founding of the University of London School of Librarianship and Archives in 1919 and the opening of nine library schools attached to technical colleges after World War II gave more students the opportunity for full-time study.

The nine library schools attached to technical colleges do not set their own examinations, but offer courses (of a year's duration) to prepare students to take the Registration Examination of the Library Association. Some of the larger schools offer an additional year of preparation for the Final Examination.

The University of London occupies a special position. Its courses in librarianship are on the graduate level and it is permitted by the Library Association to arrange its own curriculum and set its own examinations. Its entrance requirements include an honors degree, a sound knowledge of Latin, the ability to use French and German reference works without difficulty, and some full-time experience (normally a year) in a good library. The school also requires three weeks of supervised practice work in approved libraries during the academic year that is spent in London. In addition to successful completion of seven examinations, each candidate must prepare a bibliography or a thesis on an approved topic and must present a certificate stating that he has been employed full time (and given satisfactory service) 
in an approved library tor a period of at least twelve months. Fulfillment of these requirements leads to the award of the Academic Post Graduate Diploma in Librarianship.

The postwar years have seen some lively arguments about education for librarianship in the United Kingdom. In 1957, the Library Association set up a Syllabus Sub-committee which reviewed the matter and presented a report in 1960. The committee felt it would be unwise to disturb the existing structure unduly because employers now accept it and because the Ministry of Education recognizes the F.L.A. as the equivalent of a university degree. The possibility of making librarianship entirely a graduate profession was considered but felt to be impractical at the present time. However, it was agreed that higher entrance requirements would be necessary.

The committee reviewed the L.A. examinations at all levels and recommended numerous changes. Among these is the abolition of the First Professional Examination. As a substitute for it, the minimum entrance requirement is to be raised to four passes in the General Certificate of Education of which at least two (compared with one at present) must be at the Advanced level. As at present, one of these must be in English. This leaves only the Registration and Final examinations to be set by the Library Association.

The proposed Registration Examination will attempt to measure competence in a group of "core" subjects common to all types of libraries by means of four three-hour examinations. Competence in the bibliography and librarianship of a special subject field will be tested by means of a fifth examination in a specialty chosen by the student from a list of nine recommended fields. All parts of the examination will have to be written at the same time, though a student who fails in one part will be allowed to take that part over at a later date. This pro- cedure is designed to encourage full-time study as a method of preparing for the examination.

The new Final Examination will consist of six three-hour papers chosen from three groups (at least one from each group). Group A will deal with types of libraries. Group B will deal with techniques. Group $\mathrm{C}$ will cover the bibliography and librarianship of some twentysix subject fields.

If the recommended changes meet with the approval of the Library Association, the first examinations under the new system will be held in June 1963.

\section{The Canadian System}

Education in Canada is primarily the responsibility of the ten provincial governments and the local authorities. Pupils ordinarily begin school at the age of six. A period of 11 to 13 years may elapse between the beginning of elementary and the completion of secondary education. The most common period is 12 years, divided on the $8-4$ or the $6-3-3$ plan.

As a means of ensuring educational uniformity and as a basis for admission to universities, each provincial department of education conducts two sets of "matriculation" examinations for high school graduates. "Junior" matriculation corresponds to graduation from an American high school. The courses leading to "senior" matriculation are similar to those offered in the freshman year at American universities.

Canadian universities generally draw a distinction between pass (or ordinary, or general) courses and honors courses. The former are general in nature and normally require three years of study beyond senior matriculation. The latter are more specialized and usually require four years beyond senior matriculation.

The standard method of becoming a librarian in Canada is the same as in this country: graduation from an ap- 
proved university plus a year of graduate study at a library school accredited by the American Library Association. The library schools at McGill and the University of Toronto have received ALA accreditation. They grant the Bachelor of Library Science (B.L.S.) degree for one academic year (i.e. two semesters) of graduate study in library science, and the Master of Library Science (M.L.S.) degree for an additional academic year of advanced study and research in this field.

Not all Canadian librarians accept the standard pattern outlined above. Disagreement centers chiefly on two points: (1) the position of graduates of nonaccredited Canadian schools, and (b) the appropriate type of professional recognition to be given British librarians who have settled in Canada.

At least two library schools attached to universities of great repute (University of Montreal and University of Ottawa) offer graduate training in library science but are not accedited by the ALA. The courses appear to be of high standard and some of the most distinguished librarians in Canada serve as extra-mural lecturers. These schools have not been refused ALA accreditation. They have never sought it. Those who support their viewpoint tend to favor national autonomy and to be fearful of undue American influence. They point to imperfections in the ALA policy of accreditation and are often critical of the new programs of American library schools. They point out, in addition, that standards need to be fitted to a graduate degree scheme and that the Canadian pattern differs significantly from the American. Finally, they argue that Canada needs an accreditation plan with authority and competence for French- as well as English-language universities.

The proper equation of British and Canadian standards of professional education is an equally explosive issue. Since 1948, the Canadian Library Association has recognized the possession of a British university degree plus the F.L.A. as the equivalent of the Canadian B.A., B.L.S. The Library Education Workshop of 1958 went on record as similarly endorsing the Academic Post Graduate Diploma in Librarianship of the University of London. Opinions differ widely on the recognition which should be given for other forms of British training.

The American Library Association discussed the matter of professional equivalents at its Midwinter meeting of 1956 and received a report from Harold Lancour, associate director, Graduate School of Library Science, University of Illinois. No action was taken, but Dr. Lancour was asked to continue negotiations.

In the summer of 1959, an informal committee consisting of J. C. Harrison, head of the School of Librarianship, Manchester College of Technology; George Pitcher, librarian of the Kumasi College of Technology, Ghana; Bertha Bassam, director of the University of Toronto Library School; Lester Asheim, dean of the University of Chicago Graduate Library School, and Robert L. Gitler, executive secretary of the Library Education Division of ALA, met in Urbana under the chairmanship of Dr. Lancour.

\section{Minimum ReQuirements Recommended}

The committee recommended the following table of minimum requirements:

Canada a) Bachelor's degree from an approved institution.

b) B.L.S. degree from a library school accredited by the ALA and CLA.

U. S. a) Bachelor's degree from an approved institution.

b) M.S., M.A., M.L.S. (or similar degree) from a library school accredited by the ALA.

U. K. a) Bachelor's degree from an approved institution.

b) One year of study in one of the ten library schools approved by the Library Association. 
c) Possession of the Associateship of the British Library Association.

These proposals mark a real step forward in the matter of international library cooperation, although they do leave a few questions unanswered. For example, no mention is made of the recognition to be accorded the holder of a British university degree plus the F.L.A. or the Academic Post Graduate Diploma in Librarianship of the University of London. By implication at least, these qualifications are ranked somewhere above the minimum, perhaps at the level of the Canadian M.L.S. or the old-style sixth-year American master's degree. At some time in the future, more will have to be said about the holders of the F.L.A. and A.L.A. who are not university graduates. It might be helpful to determine how their training compares with that of American librarians who hold bachelors' degrees with majors or minors in library science. For the present, however, the most important point is that the recommendations establish a sound framework within which the details can be negotiated in a spirit of harmony and fairness. Let us hope that constructive action will be taken at the 1961 conferences of our three professional associations.

\section{Selective Bibliography}

Canadian Library Association. Proceedings of the Library Education Workshop, Chateau Frontenac, Quebec City, Saturday, June 14, 1958 (Ottawa: The Association, 1958).

Commonwealth Universities Yearbook, 1960, ed. (London: The Association of Universities of the British Commonwealth, 1960.)

"Council Meetings Nov. 20-24, 1959," Canadian Library, XVI (1960), 186-188.

Lancour, Harold, "Equating Professional Qualifications," Journal of Education for Librarianship, I (1960), 22-32.

The Library Association. Students' Handbook 1960 (London: The Library Association, 1960).

London. University. School of Librarianship and Archives. Prospectus 1959/60. (London: University, 1959).

Ower, Bernard, "Report on British Library Education," Feliciter, III (1958), 17-41.

Paullin, L. V. "Revision of Syllabus: A Statement," Library Association Record, LXII (1960), p. 219-225.

"Reports of Certification and Federal Aid Committees," Canadian Library, XVI (1959), 86.

Flora B. Ludington, Williston Memorial Library, Mt. Holyoke College, South Hadley, Mass.; Eli Oboler, Idaho State College Library, Pocatello; Benjamin B. Richards, White Library, Kansas State Teachers College, Emporia; and Dr. Tauber.

Articles for future use in $C R L$ should be directed to Mr. Harwell, College and Research Libraries, Bowdoin College Library, Brunswick, Me. Material to be used in the compilation of the news sections of the magazine (notes about buildings, publications, appointments, etc.) should be sent to Mrs. Mary Falvey, Publications Officer, ACRL Headquarters, 50 E. Huron St., Chicago 11, III. 